\title{
HEAVY METAL ACCUMULATION AND CHEMICAL COMPOSITION OF ESSENTIAL OILS OF LEMON BALM (MELISSA OFFICINALIS L.) CULTIVATED ON HEAVY METAL CONTAMINATED SOILS
}

\author{
Violina Angelova ${ }^{1}$
}

DOI: https://doi.org/10.31410/ITEMA.2020.287

\begin{abstract}
Comparative research has been conducted to allow us to determine the content of heavy metals and chemical composition of lemon balm oils, as well as to identify the possibility of lemon balm growth on soils contaminated by heavy metals. The experimental plots were situated at different distances of $0.5 \mathrm{~km}$, and $15 \mathrm{~km}$, respectively, from the source of pollution the Non-Ferrous-Metal Works (MFMW) near Plovdiv, Bulgaria. On reaching the flowering stage the lemon balm plants were gathered. The content of heavy metals in leaves of lemon balm was determined by ICP. The essential oils of the lemon balm were obtained by steam distillation in laboratory conditions which were analyzed for heavy metals and chemical composition was determined. Lemon balm is a plant that is tolerant to heavy metals and can be grown on contaminated soils. Heavy metals do not affect the development of lemon balm and the quality and quantity of oil obtained from it. Forty components were identified in the oils. The quantity of identified compounds corresponds to $98.82-98.83 \%$ of the total oil content. Among the detected compounds, beta-citral (neral) (19.31-20.78\%), alfa-citral (geranial) (18,65-19,12\%), $\beta$-caryophyllene (14.76-16.28\%), $\alpha$-cadinol $(3.88-4.74 \%)$, geranyl acetate (3.49-3.59\%), trans-geraniol (3.40-3.51\%), germacrene (3.18-3.28\%), citronellal (2.94$3.03 \%)$, nerol (2.63-2.71\%), neryl acetate (2.42 -2.49\%) were the major compounds. The essential oil of Melissa officinalis $L$. can be a valuable product for farmers from polluted regions.
\end{abstract}

Keywords: Contaminated soils, Essential oil composition, Heavy metals, Lemon balm.

\section{INTRODUCTION}

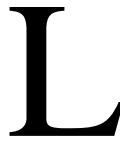
emon balm (Melissa officinalis) is a perennial herbaceous plant of the family Lamiaceae. The plant is grown mainly in Germany, France, Italy, Romania, Bulgaria and North America [1-2]. It reaches a height of 70-150 cm. The leaves have a mild lemon scent. At the end of summer, small flowers full of nectar appear, they attract bees, hence the name Melissa (Greek for "honey bee"). The citrus aroma of lemon balm is due to the terpenes citral and geraniol, citronellal, citronellol and geranyl acetate [3]. The above-ground part of the lemon balm is used as a spice and herbal tea, in medicine, in the perfume and cosmetics industry, in folk medicine. Traditionally in Bulgaria it is used for making tea, as well as for making bowles and liqueurs. Lemon balm tea is used in nervous sleep disorders and gastrointestinal disorders [4], lowering the temperature and relieving headaches caused by stress.

The oil contains terpenes (monoterpenes, sesquiterpenes and triterpenes), phenolic compounds (phenolic acids, flavonoids and tannins) [5-6]. The main active ingredients of M. officinalis are volatile compounds (geranial, neral, citronellal and geraniol), triterpenes (ursolic acid and

1 Department of Chemistry, Agricultural University - Plovdiv, Bulgaria 
oleanolic acid) [7], flavonoids and phenolic acids [8-9] such as rosemary acid [10] and caffeic acids [11], phenylpropanoid heteroside [12]. M. officinalis essential oil is used because of its antimicrobial activity [13], antiviral [14], antibacterial, antioxidant and insect repellent properties [15]. There is evidence that lemon balm has a positive effect on patients with Alzheimer's disease [6].

The chemical composition of balm mint oil has been the subject of many studies around the world. In most studies, in the essential oils from $\mathrm{M}$. officinalis has been found to be characterized mainly by oxygenated monoterpenes and sesquiterpenes. The analysis of essential oils indicated some major constituents, like geranial, neral and citronellal [6, 10, 1620], (E)-caryophyllene and caryophyllene oxide [10,21], linalool [16], geraniol [22], thymol [23], $\alpha$-pinene [21], $\beta$-pinene [21,24], carvacrol and iso-menthone [20], decadienal [25] and trans-carveol [26]. The composition of the oil depends on various factors, such as genetic origin, habitat, environmental conditions, physiological stage (time of harvest, plant parts of the plant used to extract the essential oil, soil composition, etc.).

It has been found that the medicinal plants can accumulate larger amounts of heavy metals such as $\mathrm{Cd}, \mathrm{As}, \mathrm{Pb}$ and $\mathrm{Hg}$ compared to other plants [27].

Some medical plants such as mint, St. John's wort, lavender, marigold, marshmallow, cumin, garlic, garden sorrel, hemp and others can accumulate large amounts of toxic heavy metals in their tissues. However, Zheljazkov [28] demonstrated that aromatic crops may not have significant phytoremediation potential, but growth of these crops in metal contaminated agricultural soils is a feasible alternative. Aromatic crops can provide economic return and metal-free final product, the essential oil. The essential oil of aromatic plants does not contain heavy metals, although there is an accumulation in the plant biomass [28-29].

The plants of the Lamiaceae family are also widespread in world and have a large biomass production capacity. However, there are no studies on the possibilities of heavy metals accumulation in Melissa officinalis L. when grown on contaminated soils. There are no comprehensive studies on the relationship among the total content of heavy metals in the soil, their uptake by the leaves of balm mint and quality of oil.

The purpose of this work is to conduct a comparative study, which allows us to determine the heavy metal accumulation in balm mint, the quality of balm mint oil, as well as the possibilities to grown on heavy metal contaminated soils.

\section{MATERIAL AND METHODS}

The experiment was performed on agricultural fields contaminated by $\mathrm{Zn}, \mathrm{Pb}$ and $\mathrm{Cd}$, situated at different distances $(0.5$, and $15.0 \mathrm{~km})$ from the source of pollution, the NFMW near Plovdiv (Non-Ferrous Metal Works), Bulgaria.

Characteristics of soils are shown in Table I. The soils were slightly neutral to alkalic with moderate content of organic matter and essential nutrients (N, P and K) (Table I). The pseudototal content of $\mathrm{Zn}, \mathrm{Pb}$ and $\mathrm{Cd}$ is high and exceeds the maximum permissible concentrations (MPC) in soil 1 (S1) (Table 1). 
Table 1. Characterization of the soils

\begin{tabular}{|c|c|c|c|c|c|c|c|c|c|}
\hline Parameter & $\mathrm{pH}$ & $\begin{array}{c}\mathrm{EC}, \\
\mathrm{dS} / \mathrm{m}\end{array}$ & $\begin{array}{c}\text { Organic } \\
\mathrm{C} . \%\end{array}$ & $\begin{array}{c}\mathrm{N} \\
\text { Kjeldal,\% }\end{array}$ & $\begin{array}{c}\mathrm{P}, \\
\mathrm{mg} / \mathrm{kg}\end{array}$ & $\begin{array}{c}\mathrm{K}, \\
\mathrm{mg} / \mathrm{kg}\end{array}$ & $\begin{array}{c}\mathrm{Pb}, \\
\mathrm{mg} / \mathrm{kg}\end{array}$ & $\begin{array}{c}\mathrm{Zn}, \\
\mathrm{mg} / \mathrm{kg}\end{array}$ & $\begin{array}{c}\mathrm{Cd}, \\
\mathrm{mg} / \mathrm{kg}\end{array}$ \\
\hline $\begin{array}{c}\text { Soil 1 (S1) } \\
0,5 \mathrm{~km}\end{array}$ & 7,4 & 0,15 & 2,2 & 0,34 & 625,6 & 6960 & 2509,1 & 2423,9 & 64,3 \\
\hline $\begin{array}{c}\text { Soil 2 (S2) } \\
15 \mathrm{~km}\end{array}$ & 7,5 & 0,15 & 1,54 & 0,12 & 387,3 & 6780 & 49,4 & 172,7 & 1,0 \\
\hline
\end{tabular}

MPC (pH 6.0-7.4) - Pb-100 mg/kg, Cd-2.0 mg.kg, Zn-320 mg/kg

MPC (pH > 7.4) - Pb-100 mg/kg, Cd-3.0 mg/kg, Zn-400 mg/kg

The test plant was Melissa officinalis L. Balm mint is grown according to conventional technology. Five plants of each of the areas were used for the analysis. Upon reaching the stage just prior to blooming, balm mint was harvested and the content of $\mathrm{Pb}, \mathrm{Zn}$ and $\mathrm{Cd}$ in leaves was determined. The essential oil of the balm mint was obtained by steam distillation in laboratory conditions which was analyzed for heavy metals content and its chemical composition was determined.

Pseudo-total content of metals in soils was determined in accordance with ISO 11466 [30]. The available (mobile) heavy metals contents were extracted in accordance with ISO 14870[31] by a solution of DTPA. The contents of heavy metals ( $\mathrm{Pb}, \mathrm{Zn}$ and $\mathrm{Cd}$ ) in the plant material (leaves) and in the essential oils of sage were determined by the method of the dry mineralization. The quantitative measures were carried out by ICP method (Jobin Yvon Emission - JY $38 \mathrm{~S}$, France). Digestion and analytical efficiency of ICP was validated using a standard reference material of apple leaves (SRM 1515, National Institute of Standards and Technology, NIST). The chemical composition of the oil was determined on a gas chromatograph PYE UNICAM series 204, equipped with a flame ionization detector and a capillary column CARBOWAX 20 $\mathrm{M}$ with hydrogen carrier gas.

\section{RESULTS AND DISCUSSION}

\section{Soils}

The results presented in Tables I and II show that in the soil samples S1 (taken from the area situated at the distance of $0.5 \mathrm{~km}$ from NFMW), the reported values for $\mathrm{Pb}$ were exceeding MPC approved for Bulgaria and reached to $2509.1 \mathrm{mg} / \mathrm{kg}$. In the area located at a distance of $15 \mathrm{~km}$, the contents of $\mathrm{Pb}$ significantly reduce to $49.4 \mathrm{mg} / \mathrm{kg}$. Similar results were obtained for $\mathrm{Cd}$ and $\mathrm{Zn}$. The results for the mobile forms of the metals extracted by DTPA show that the mobile forms of $\mathrm{Cd}$ in the contaminated soils are the most significant portion of its total content and reached to $57,2 \%$, followed by $\mathrm{Pb}$ with $33,8 \%$ and $\mathrm{Zn}$ with $9,8 \%$.

In the soil located at a distance of $15 \mathrm{~km}$ from NFMW the mobile forms of Cd are the most significant part of it.

Table 2. DTPA-extractable $\mathrm{Pb}, \mathrm{Zn}$ and $\mathrm{Cd}(\mathrm{mg} / \mathrm{kg})$ in soils sampled from NFMW

\begin{tabular}{|l|c|c|c|c|c|c|}
\hline \multirow{2}{*}{ Soils } & \multicolumn{2}{|c|}{$\mathrm{Pb}$} & \multicolumn{2}{c|}{$\mathrm{Cd}$} & \multicolumn{2}{c|}{$\mathrm{Zn}$} \\
\cline { 2 - 7 } & $\mathrm{mg} / \mathrm{kg}$ & $\%^{*}$ & $\mathrm{mg} / \mathrm{kg}$ & $\%$ & $\mathrm{mg} / \mathrm{kg}$ & $\%$ \\
\hline S1 $(0.5 \mathrm{~km})$ & 849.1 & 33.8 & 36.8 & 57.2 & 236.8 & 9.8 \\
\hline $\begin{array}{c}\text { S2 }(15.0 \\
\mathrm{km})\end{array}$ & 21.5 & 43.5 & 0.7 & 70 & 38.9 & 22.5 \\
\hline
\end{tabular}

*DTPA -extractable / total content 


\section{Content of Heavy Metals in balm mint}

A significant accumulation of $\mathrm{Pb}$ is found in the leaves of the balm mint. The content of this element reaches up to $143.5 \mathrm{mg} / \mathrm{kg}$ in leaves of the balm mint grown at a distance of $0.5 \mathrm{~km}$ from NFMW (S1) (Table 3) and was very high beyond the proposed guide value for medicinal plants. Kabata Pendias [27] quote that normally there are $5-10 \mathrm{mg} / \mathrm{kg} \mathrm{Pb}$ in a plant material. Schilcher and Peters [32] proposed to set the limits for $\mathrm{Pb}$ in medicinal plants at $10 \mathrm{mg} / \mathrm{kg}$, due to their little portion in the human diet and incomplete extraction of $\mathrm{Pb}$ during tea preparation. The World Health Organization (WHO) recommends limits for various medicinal plants of not more than $10 \mathrm{mg} / \mathrm{kg} \mathrm{Pb}$ and $0.3 \mathrm{mg} / \mathrm{kg} \mathrm{Cd}$ in the final dosage form of the plant material. The relatively high amount of $\mathrm{Pb}$ may be caused by the morphological characteristics of the plant. The leaves of balm mint were covered with pappus, which contributed to the fixing of the aerosol pollutants and for their accumulation there. The content of $\mathrm{Cd}$ in the leaves of balm mint grown at a distance of $0.5 \mathrm{~km}$ from NFMW reaches up to $2.25 \mathrm{mg} / \mathrm{kg}$, values considered to be nontoxic to plants. According to Kabata-Pendias [27] $5.0 \mathrm{mg} / \mathrm{kg} \mathrm{Cd}$ is considered to be a toxic value for the plants. The content of $\mathrm{Zn}$ in the leaves of balm mint grown at a distance of $0.5 \mathrm{~km}$ from NFMW reaches up to $184.7 \mathrm{mg} / \mathrm{kg}$, as these values are also less the critical values for plants - 100-400 mg/kg. With increasing the distance from NFMW a clear trend is seen towards reducing the content of heavy metals in the leaves of the studied crop. The content of heavy metals in the leaves of the balm mint grown at $15 \mathrm{~km}$ from NFMW reaches up to 1.6 $\mathrm{mg} / \mathrm{kg} \mathrm{Pb}, 0.08 \mathrm{mg} / \mathrm{kg} \mathrm{Cd}$ and $17.7 \mathrm{mg} / \mathrm{kg} \mathrm{Zn}(\mathrm{S} 2)$.

The heavy metal content in the essential oil from balm mint was also determined. The results obtained show that the majority of the heavy metals contained in the leaves of the balm mint do not pass into the oil during the distillation, therefore their content in the oil are much lower. In the process of oil extraction by distillation, heavy metals remain in the extracted plant residues, limiting the quantities of heavy metals in the commercial oil product. $\mathrm{Pb}$ content in the essential oil of balm mint reaches up to $0.2 \mathrm{mg} / \mathrm{kg}$, Zn up to $4.5 \mathrm{mg} / \mathrm{kg}$, while the content of $\mathrm{Cd}$ is below the limits of the quantitative measurement of the method used. Significantly lower are the figures in the essential oil of balm mint grown at a distance of $15 \mathrm{~km}$ from NFMW $-0.03 \mathrm{mg} / \mathrm{kg} \mathrm{Pb}$ and $1.6 \mathrm{mg} / \mathrm{kg} \mathrm{Zn} \mathrm{(S2).}$

These results strongly suggest that the main part of $\mathrm{Pb}, \mathrm{Cd}$ and $\mathrm{Zn}$, contained in the leaves of balm mint, cultivated $0.5 \mathrm{~km}$ from the NFMW, does not pass into the oil obtained, its content in the oil are lower according the Directive 76/768/EEC for plant extracts $(20 \mathrm{mg} / \mathrm{kg} \mathrm{Pb}$ and 2 $\mathrm{mg} / \mathrm{kg} \mathrm{Cd}$ ) and it can be used for cosmetics. This result is very important, given the commercial value of the essential oil extracts of the aromatic and medicinal plants. The accumulation of heavy metals in the end products, obtained after the processing of the aboveground parts of the plant, was within the limits of the permissible values to the normative requirements for ecologically clean product.

Table 3. Content of $\mathrm{Pb}, \mathrm{Cd}$ and $\mathrm{Zn}(\mathrm{mg} / \mathrm{kg})$ in leaves and essential oil of balm mint

\begin{tabular}{|l|c|c|c|c|c|c|}
\hline \multirow{2}{*}{ Soils } & \multicolumn{2}{|c|}{$\mathrm{Pb}$} & \multicolumn{2}{c|}{ Cd } & \multicolumn{2}{c|}{ Zn } \\
\cline { 2 - 7 } & Leaves & Oil & Leaves & oil & Leaves & oil \\
\hline S1 $(0.5 \mathrm{~km})$ & 143.5 & 0,2 & 2.25 & n.d. & 184.7 & 4.5 \\
\hline S2 $(15.0 \mathrm{~km})$ & 1.6 & 0.03 & 0.08 & n.d. & 17.7 & 1.6 \\
\hline
\end{tabular}

n.d.-non detectable 


\section{Effect of heavy metals on the quality of the oil}

The results of the chromatographic analysis of essential oils obtained by processing of leaves balm mint grown at a different distance from NFMW are presented in Table 4. The values of the main components of the essential oil of balm mint are compared with the data obtained from all cited references.

No significant differences were observed in the composition between the oils obtained from the areas of different distance from NFMW. The yield for balm mint oils ranged between $0.245 \%$ (S1) and $0.25 \%$ (S2). Ozturk [33] found that the content of essential oil in lemon balm varies between 0.02 and $0.30 \%$, which is much lower than other plants in the family Lamiaceae. According to Turhan [34] the content of essential oil and its composition depend on the cutting height of the lemon balm. It was found that the content of essential oil in the upper part (young leaves) is $0.39 \%$, while in the whole leaf mass it is $0.14 \%$. For this reason, the production costs and the price of the essential oil are very high on the market. Souihi [35] found that the essential oil content in Tunisia is very low $(0.032 \%$, ), the content in the oil from Turkey varies from 0.01 to $0.25 \%$. [36], $0.03-0.067 \%$ [37] to $0.27-0.36 \%$, [38], from $0.06-0.16 \%$ in Iran oil [39], from 0.08 to $0.25 \%$ in the oil from Poland [16], $0.25 \%$ in the oil from Germany [40], and from 0.5 to $0.8 \%$ [40] in the oil from Spain.

Forty compounds representing $98.82-98.83 \%$ of the oil were identified, 21 of which were above $1 \%$. The obtained results show that oxygen-containing monoterpenes (neral and geranial) and sesquiterpenes hydrocarbon ( $\beta$-caryophyllene) predominate in the essential oils.

It is noteworthy that the content of oxygen-containing monoterpenes neral and geranial, and the sesquiterpene alcohol $\alpha$-cadinol is higher in the balm mint oil obtained from the contaminated area, while the content of $\beta$-caryophyllene is lower. No significant difference was found for the other components.

The monoterpene aldehyde citronellal determines the sweet floral aroma of rose. The content of citronellal in the studied oils varies from $2.94 \%$ (S1) to $3.03 \%$ (S2), whereas significantly higher values were found by Popova [41] for the Bulgarian commercial oil (18.5\%). According to literature data, the content of citronellal varies widely - from $0.2 \%$ in the oil from Cuba [42] to $40 \%$ in the oil from France (40\%) [43]. Some essential oils, such as those of Brazilian origin, do not contain citronellal [17]. Shamsi [44] found that the amount the amount of citronellal is lower in the leaves of the upper third part (2.82\%) compared to the total leaf mass $(6.44 \%)$.

The monoterpene aldehyde (Z)-citral (neral) causes the sweet citrus aroma of lemon. The content of beta-citral (neral) in the studied oils varies from $19.31 \%$ (S2) to $20.78 \%$ (S1). According to literature data, the content of neral varies widely in lemon balm oil - from 4.3 to $43.8 \%$. The highest content of neral was established in the oils from Cuba (29.9\%) [42], Brazil $(39.3 \%)$ [17] and Iran (43.8\%) [39]. The content of neral is significantly lower in the oil from Scotland (4.3\%) [45], and Bulgaria (5.9\%) [41], while neral is not found in the oil from Greece. The monoterpene aldehyde (E)-citral (geranial) determines the citrus aroma of lemon. The content of alpha-citral in the oils varies from $18.65 \%$ (S2) to $19.12 \%$ (S1). According to literature data, the content of geranial varies widely - from 6.6 to $47.3 \%$. The highest values were found in the oils from Cuba (41.0\%) [42] and Brazil (47.3\%) [17], while in the oils from Greece and Scotland [45] no geranial is contained. According to Hefendelh [46], the young leaves have higher citral content, while the older leaves have higher citronellal content. Similar results were reported by Mrlianova [47], who found that the amount of citral isomers (neral 
and geranial) was higher in the leaves of the upper third part of the lemon balm $(59.74 \%)$ than in the leaves of the whole aboveground mass (56.87\%).

Sesquiterpene, bicyclic b-caryophyllene causes spicy woody citrus aroma. The content of $\beta$ Caryophyllene in the studied oils varies from 16.280 (S2) and $14.762 \%$ (S1). Similar results were obtained by Allahverdiyev [5] for Turkish oils, which are characterized by a high content of $\beta$-carophylene (14.2\%). Slightly lower results were obtained for the content of $\beta$ carophylene in the oils from Slovakia (4.2\%) [48], Serbia (4.6\%) [49], Iran (4.9\%) [39], and Egypt $(4.9 \%$,$) [50]. Significantly lower values were reported for the oil from Algeria (1.3 \%)$ and France (2.4\%) [43]. Mrlianova [47] b) found that the amount of beta-caryophyllene was higher in the leaves of the upper third of the lemon balm (6.97\%) than in the total leaf mass $(5.13 \%)$,

The content of geraniol varies from 1.358 (S2) to $1.317 \%$ (S1). According to literature data, the geraniol content varies from $0.2 \%$ to $15.2 \%$, with higher values found in oils from Serbia (3.4\%) [49], Egypt (4.2\%) [50], Scotland (5.73\%) [45], Bulgarian commercial oil (15.72\%) [41], and significantly lower in oil from Algeria (0.6\%)[43].

Table 4. Composition of oil (\%) obtained by processing fresh leaves of balm mint

\begin{tabular}{|c|c|c|c|c|c|}
\hline \multirow{2}{*}{ № } & \multirow{2}{*}{ Compound } & \multirow{2}{*}{ RI } & $\mathrm{S} 1(0.5 \mathrm{~km})$ & $\mathrm{S} 2(15.0 \mathrm{~km})$ & \multirow{2}{*}{ Reference } \\
\hline & & & \multicolumn{2}{|c|}{$\%$ of TIC } & \\
\hline 1 & $\alpha$-Pinene & 939 & 0,367 & 0,356 & \\
\hline 2 & $\beta$-Pinene & 979 & 0,934 & 0,906 & \\
\hline 3 & 1-Octen-3-ol & 982 & 0,119 & 0,075 & \\
\hline 4 & beta-Myrcene & 990 & 0,25 & 0,243 & \\
\hline 5 & Limonene & 1029 & 1,879 & 1,822 & trace -57.5 \\
\hline 6 & cis-beta-Ocimene & 1040 & 1,176 & 1,141 & \\
\hline 7 & trans-beta-Ocimene & 1050 & 0,577 & 0,56 & \\
\hline 8 & beta-Linalool & 1097 & 0,988 & 0,958 & trace -1.3 \\
\hline 9 & cis- Rose oxide & 1110 & 0,339 & 0,329 & \\
\hline 10 & trans-Rose oxide & 1128 & 0,466 & 0,452 & \\
\hline 11 & Verbenol & 1134 & 0,339 & 0,329 & \\
\hline 12 & Citronellal & 1151 & 3,03 & 2,939 & $0.2-43.8$ \\
\hline 13 & trans-Carveol & 1195 & 0,149 & 0,144 & \\
\hline 14 & Myrtenol & 1198 & 1,359 & 1,318 & \\
\hline 15 & Menthol & 1173 & 0,936 & 0,908 & \\
\hline 16 & Isomenthol & 1180 & 0,384 & 0,373 & \\
\hline 17 & $\alpha$-Terpineol & 1187 & 0,164 & 0,159 & \\
\hline 18 & Nerol & 1228 & 2,709 & 2,628 & \\
\hline 19 & Geraniol & 1230 & 1,358 & 1,317 & $0.2-15.2$ \\
\hline 20 & beta-Citral (Neral) & 1240 & 19,308 & 20,783 & $4.3-39.3$ \\
\hline 21 & trans-Geraniol & 1255 & 3,505 & 3,4 & \\
\hline 22 & $\begin{array}{l}\text { (S)-(-)-Citronellic } \\
\text { acid, methyl ester }\end{array}$ & 1261 & 1,253 & 1,215 & \\
\hline 23 & alfa-Citral (Geranial) & 1270 & 18,649 & 19,116 & $6.6-47.3$ \\
\hline 24 & Citronellyl acetate & 1354 & 0,426 & 0,413 & $0.6-7.24$ \\
\hline 25 & Neryl acetate & 1364 & 2,493 & 2,418 & \\
\hline 26 & Geranyl acetate & 1383 & 3,593 & 3,485 & \\
\hline 27 & $\beta$-Caryophyllene & 1419,1 & 16,28 & 14,762 & $1.3-15.3$ \\
\hline
\end{tabular}


HEAVY METAL ACCUMULATION AND CHEMICAL COMPOSITION OF ESSENTIAL OILS OF LEMON BALM (MELISSA OFFICINALIS L.) CULTIVATED ON HEAVY METAL CONTAMINATED

SOILS

\begin{tabular}{|l|l|c|c|c|c|}
\hline 28 & $($ E)- $\beta$-Farnesene & 1460 & 0,604 & 0,586 & \\
\hline 29 & Germacrene D & 1480 & 3,277 & 3,179 & trace -2.14 \\
\hline 30 & Caryophyllene Oxide & 1581 & 1,166 & 1,131 & $1.2-12.6$ \\
\hline 31 & n-Pentacosane & 1500 & 1,192 & 1,156 & \\
\hline 32 & n-Hexacosane & 1600 & 1,041 & 1,009 & \\
\hline 33 & tau.-Cadinol & 1629 & 1,166 & 1,131 & \\
\hline 34 & tau.-Muurolol & 1631 & 1,366 & 1,325 & \\
\hline 35 & $\alpha$-Cadinol & 1653 & 3,884 & 4,737 & \\
\hline 36 & n-Heptacosane & 1700 & 0,83 & 0,806 & \\
\hline 37 & n-Octacosane & 1800 & 0,115 & 0,088 & \\
\hline 38 & n-Nonacosane & 1900 & 0,237 & 0,229 & \\
\hline 39 & n-Eicosane & 2000 & 0,565 & 0,548 & \\
\hline 40 & n-Heneicosane & 2100 & 0,353 & 0,342 & \\
\hline & Total & & 98,826 & 98,816 & \\
\hline & Yoeld, $\%$ & & 0.24 & 0.25 & \\
\hline
\end{tabular}

RI - Relative Index; TIC - Total Ion Current

The content of monoterpene geranyl acetate varies from 3.49 (S1) to $3.59 \%$ (S2). Slightly higher values of geranyl acetate were found in the oil from Slovakia (5.9\%) [48], Iran (7.1\%) [39] and Bulgarian commercial oil (7.24\%) [41].

Sesquiterpene oxide b-caryophyllene oxide causes the woody spicy aroma. The content of caryophyllene oxide varies from 1.166 (S2) to 1.131 (S1). Similar results were obtained for the oils from Algeria (1.3\%) and Serbia (1.7\%) [49]. Significantly higher results were obtained for the oils from Iran (2.7\%) [39], Cuba (5.3\%) [42], Slovakia (8.35\%) [48], Egypt (10.0\%,) [50]. The highest values were reported in the oil from Jordan, in which caryophyllene oxide is the dominant ingredient (43.6\%) [51].

Most studies have shown that oxygen monoterpenes, such as the isomers of citral (geranial and neral), citronellal and geraniol, predominate in the oil from M. officinalis [49,52]. For example, lemon balm oils from Serbia [49], Slovakia [48], Egypt [50], France [43] and Iran [39] are characterized by a high content of geranial, neral and citronellal. Citral, citronellal and caryophyllene oxide [44] dominate in the oils obtained in Algeria. Meftahizade [52], report that the main constituents of the essential oil are citral (geranium and neral), citronellal, geraniol, beta-pinene, alpha-pinene, and beta-caryophyllene. According to Bagdad and Coşge [36] the main components of the oil obtained in Turkey are citronellal (39\%), citral (33\%), citronellol, linalool and geraniol, while according to Allahverdiyev [5] the oil is dominated mainly by sesquiterpene hydrocarbons $\beta$-cubebene (15.41\%) and $\beta$-caryophyllene $(14.24 \%)$. The sesquiterpene hydrocarbons $\beta$-cubeben (39\%) and terpinolene $(9.6 \%)$ also predominate in the oil obtained in New Zealand [3]. Van den Berg [53] reported that the main components in the oil were germacrene D (34.79-51.50\%), sabinene (0.91-14.68\%), $\beta$-caryophyllene (7.27$12.66 \%)$ and $\beta$-pinene $(0.53-8.03 \%)$, whereas limonene is a major component in the oil obtained in Scotland (57.5\%) [45].

The results of this study show that balm mint oil belongs to the citral $/ \beta$-caryophyllene chemotype - neral $(19,308-20,783 \%)>$ and geranial $(18,649-19,116 \%)>\beta$-caryophyllene $(14,762-16.28 \%)$. Oils from Tajikistan [54], Turkey (24], Romania [19], Serbia [18], Poland [16], and Brazil [17], belong to geranial/neral chemotype, olls from Iran - to geranol/caryophyllene oxide chemotype [25], while from Egypt [55], Turkey [23], and Italy 
[20] - to citronellal chemotype, oils from Iran - to $\alpha$-pinene and caryophyllene oxide chemotype [56], oils from Greece - to caryophyllene-oxide/ $\beta$-caryophyllene/ $\beta$-pinene chemotype [21]. The studied oils are a new chemotype of balm mint oil. So far, in the scientific literature there is no information about such a type of citral/ $\beta$-caryophyllene chemotype of oils. The results from the present study confirm that balm mint have a unique chemical composition and individual oil chemotype.

Figure 1. Classification of the identified compounds based on functional groups in oils from contaminated soils (A) and non-contaminated soils (B) (OM - oxygen-containing monoterpenes; $\mathrm{MH}$ - monoterpenic hydrocarbons; $\mathrm{SH}$ - sesquiterpene hydrocarbons; OS oxygen-containing sesquiterpenes)

A

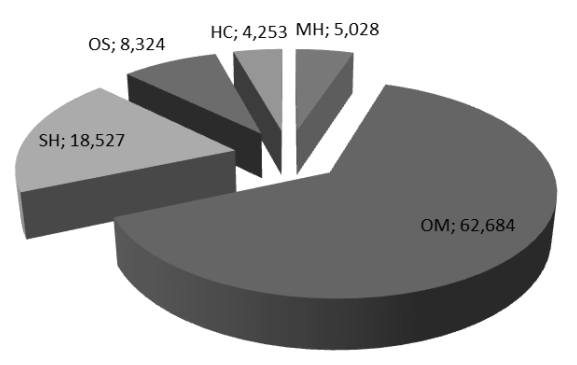

B

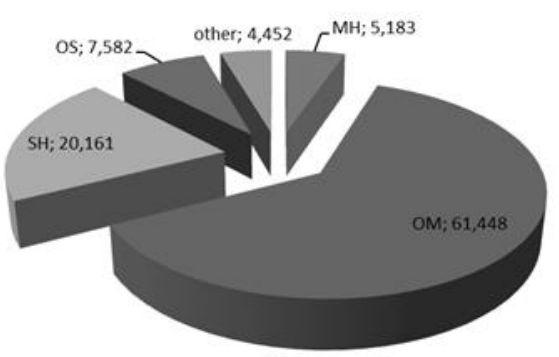

The chromatographic profile shows a complex mixture of components contained in balm mint oil. Figure 1 shows the classification of the identified compounds on the basis of functional groups. The highest is the content of oxygen-containing monoterpenes (61.448-62.684\%), followed by sesquiterpene hydrocarbons (18.527-20.161\%), oxygen-containing sesquiterpenes (7,582-8.324\%), monoterpene hydrocarbons (5.028-5.183\%), and others (4.253- 4.452\%). There are no significant differences in the profile of essential oils extracted from balm mint when grown on contaminated and uncontaminated soils. Probably the contamination of the soil with heavy metals does not affect the composition and quality of the oil.

This study shows that balm mint can be grown on heavy metal contaminated soils. The oil yield, essential oil content and essential oil compositions are similar to the oil from the uncontaminated area and to the oils currently available on the market from other countries. Therefore, essential oils extracted from balm mint grown in contaminated areas could be marketed in the same way as essential oils produced in other regions of the world.

\section{CONCLUSION}

Based on the obtained results, the following conclusions can be made:

1. Melissa oficinalis $L$. is a plant which is tolerant to heavy metals and can be grown on contaminated soils.

2. In the leaves from Melissa Oficinalis L., cultivated in the region of the NFMW, the contents of $\mathrm{Pb}, \mathrm{Zn}$ and $\mathrm{Cd}$ exceeded the Maximum permissible concentration, and could be a potential danger for men, when used as herbal tea.

3. 3.The amounts of $\mathrm{Pb}, \mathrm{Zn}$ and $\mathrm{Cd}$ in the oil of balm mint grown on contaminated soil $(\mathrm{Pb}$ $-2509.1 \mathrm{mg} / \mathrm{kg}, \mathrm{Zn}-2423.9 \mathrm{mg} . \mathrm{kg}, \mathrm{Cd}-64.3 \mathrm{mg} / \mathrm{kg}$ ) are lower than the accepted maximum values and meet the requirements of an environmentally friendly product.

4. The contamination of the soils with heavy metals does not affect the composition and quality of the oil. The content of the oxygen-containing monoterpenes neral and geranial, 
and the sesquiterpene alcohol $\alpha$-cadinol is higher in the balm mint oil obtained from the contaminated area, the content of $\beta$-caryophyllene is lower, and no significant difference was found for the other components.

5. The highest is the content of oxygen-containing monoterpenes (61.448-62.684\%), followed by sesquiterpene hydrocarbons (18.527-20.161\%), oxygen-containing sesquiterpenes (7,582-8.324\%), monoterpene hydrocarbons (5.028-5.183\%), and others (4.253- $4.452 \%)$.

6. Balm mint oil from contaminated and uncontaminated area belongs to the new type of oils- citral/ $\beta$-caryophyllene chemotype - neral $(19,308-20,783 \%)>$ geranial $(18,649$ $19,116 \%)>\beta$-caryophyllene (14,762-16.28\%).

7. Melissa Oficinalis L. could be cultivated in industrially polluted regions, as it is mainly used for obtaining essential oil. The essential oil of balm mint can be a valuable product for the farmers from the polluted areas.

Acknowledgements: The financial support by the Bulgarian National Science Fund Project DFNI H04/9 is greatly appreciated.

\section{REFERENCES}

[1] Anonymous (2003) Microsoft Encarta Encyclopedia, 1993- 2000

[2] De Sousa, A. C., Gattass, C. R., Alviano, D. S., Alviano, C. S., Blank, A. F., Alves, P. B. (2004) Melissa officinalis L. essential oil: antitumoral and antioxidant activities, Journal of pharmacy and pharmacology, vol. 56(5), pp.677-681.

[3] Bernard, S.W., Dawson, Franich, R., Meder, R., (1988) Essential oil of Melissa officinalis L. subsp. altissima (Sibthr. et Smith) Arcang, Flavour and Fragrance Journal, vol. 3(4), pp.167-170.

[4] Beloued, A. 2009. Plantes médicinales d'Algérie. Alger: Office des Publications Universitaires $\mathrm{p} 134$.

[5] Allahverdiyev, A., Duran, N., Ozguven, M., Koltas, S., (2004) Antiviral activity of the volatile oils of Melissa officinalis Against Herpes simplex virus type-2, Phytomedicine, vol. 11, pp. 657-661.

[6] Moradkhani, H., Sargsyan, E., Bibaky, H., Naseri, B., Sadat-Hosseini, M., Fayazi-Barjin, A., Meftahizade, H. (2010) Melissa officinalis L., a valuable medicine plant: A review, J. Med. Plants Res., vol.4, pp.2753-2759.

[7] Mencherini, T., Picerno, P., Scesa, C., Aquino, R., (2007) Triterpene, Antioxidant, and Antimicrobial Compounds from Melissa officinalis, J. Nat. Prod., vol.70(12), pp.18891894.

[8] Constantine, D.S., (2007) Extraction, separation and detection methods for phenolic acids and flavonoids, J Sep Sci., vol. 30, pp.3268-3295.

[9] Ziakova, A., Brandsteterova, E. (2003) Validation of HPLC determination of phenolic acids present in some Lamiaceae family plants, J Liquid Chromatogr., vol.26, pp. 443453.

[10] Toth, J., Mrlianova, M., Tekelova, D., Karenova, M., (2003) Rosmarinic acid - an important phenolic active compound of Lemon balm (Melissa officinalis L.), Acta Facult. Pharm. Univ. Comenianae, vol.50, pp. 139-146.

[11] Tagashira, M., Ohtake, Y., (1998) A New antioxidative 1, 3- benzodioxole from Melissa officinalis, Planta Med, vol. 64, pp.555-558.

[12] Mulkenst, A., Kapetanidis, I., (1988) Eugenylglucoside, a new natural phenylpropanoid heteroside from Melissa officinalis, J Nat Prod., vol. 51, pp.496-498. 
[13] Vitullo, M., Ripabelli, I., Fanelli, I,, Tamburro, M,, Delfine, S., Sammarco, L, (2011) Microbiological and toxicological quality of dried herbs, Lett Appl Microbiol., vol. 52, pp. 573-580.

[14] Adjorjan, B., Buchbauer, G., (2010) Biological properties of essential oils: an updated review, Flav Fragr J., vol. 25, pp.407-426.

[15] Spiridon, L, Colceru, S., Anghel, N., Teaca, C.A., Bodirlau, R., Armatu, A., (2011) Antioxidant capacity and total phenolic contents of oregano (Origanum vulgare), lavender (Lavandula angustifolia) and lemon balm (Melissa officinalis) from Romania, Nat Prod Res., vol. 25, pp.1657-1661.

[16] Patora, J., Majda, T., Gora, J., Klimek, B., (2003). Variability in the content and composition of essential oil from lemon balm (Melissa officinalis L.) cultivated in Poland. J. Endocrinol. Invest., vol.26(10), pp. 950-955.

[17] da Silva, S., Sato, A., Lage, C. L. S.. da Silva, San Gil, R. A., de Almeida Azevedo, D., Esquibel, M. A., (2005). Essential oil composition of Melissa officinalis L. in vitro produced under the influence of growth regulators. J. Braz. Chem. Soc., vol.16, pp. 13871390.

[18] Anicic, N. V., Dimitrijevic, S., Ristic, M. S. Petrovic, S. S., Petrovic, S. D., (2005) Antimicrobial activity of essential oil of Melissa officinalis L. Lamiaceae, Hem. Ind., vol. 59, pp. 234-247.

[19] Hancianu, M., Aprotosoaie, A. C., Gille, E., Poiata, A., Tuchilus, C., Spac, A., Stanescu, U., (2008) Chemical composition and in vitro antimicrobial activity of essential oil of Melissa officinalis L. from Romania, Rev. Med. Chir. Soc. Med. Nat. Iasi., vol.112, pp. 843-847.

[20] Martino, L. D., Feo, V. D., Nazzaro, F., (2009) Chemical composition and in vitro antimicrobial and mutagenic activities of seven Lamiaceae essential oils, Molecules, vol.14, pp.4213-4230.

[21] Basta, A., Tzakou, O., Couladi, M., (2005) Composition of the leaves essential oil of Melissa officinalis from Greece, Flav Fragr J., vol.20, pp.642-644.

[22] Hussain, A. I., Anwar, F., Iqbal, T., Bhatti, I. A., (2011) Antioxidant attributes of four Lamiaceae essential oils, Pak. J. Bot., vol. 43, pp. 1315-1321.

[23] Cosge, B., Ipek, A., Gurbuz, B., (2009) GC/MS analysis of herbage essential oil from Lemon balms (Melissa officinalis L.) grown in Turkey, J. Appl. Biol. Sci., vol.3, pp. 149152.

[24] Sari, A. O., Ceylan, A., (2002) Yield characteristics and essential oil composition of Lemon balm (Melissa officinalis L.) grown in the Aegean region of Turkey, Turk. J. Agric. For., vol. 26, pp. 217-224.

[25] Saeb, K., Gholamrezaee, S., (2012) Variation of essential oil composition of Melissa officinalis L. leaves during different stages of plant growth, Asian Pac. J. Trop. Biomed., vol. 2, pp. S547-S549.

[26] Adinee, J., Piri, K., Karami, O., (2008) Essential oil component in flower of Lemon balm (Melissa officinalis L.), Am. J. Biochem. Biotechnol., vol. 4, pp. 277-278.

[27] Kabata-Pendias, A., (2010) Trace Elements in Soils and Plants. 4th edition., Boca Raton, FL, USA: CRC Press/Taylor \& Francis Group, pp. 548.

[28] Zheljazkov, V., Craker, L. E., Xing, B., Nielsen, N. E., Wilcox, A., (2008) Aromatic plant production on metal contaminated soils, Sci. Total. Environ., vol. 395, pp. 51-62.

[29] Angelova, V.R., Grekov, D. F., Kisyov, V. K., Ivanov, K. I., (2015) Potential of Lavender (Lavandula vera L.) for Phytoremediation of Soils Contaminated with Heavy Metals, World Academy of Science, Engineering and Technology International Journal of Biological, Biomolecular, Agricultural, Food and Biotechnological Engineering, vol.9 (5), pp.514-521. 
[30] ISO 11466, (1995) Soil quality - Extraction of trace elements soluble in aqua regia.

[31] ISO 14780, (2001) Anonimous, Soil quality - Extraction of trace elements by buffered DTPA solution.

[32] Schilcher, H., Peters. H., (1990). Empfehlungen von Richtlinien und Grenzwerten fur den maximalen Blei und Cadmiumgehalt von Arzneidrogen und daraus hergestelter pharmazeutischer Zubereitungen, Pharm. Ind., vol. 52, pp.916-921.

[33] Ozturk, A., Unlukara, A., Ipek, A., Gurbuz, B., (2004) Effects of salt stress and water deficit on plant growth and essential oil content of Lemon Balm (Melissa officinalis L.). Pak. J. Bot., vol.36(4), pp. 787-792.

[34] Turhan, M., (2006) Hand book of herbal plants, chapter 4. Melissa officinalis, vol.3, pp. 184-245

[35] Souihi, M., Amri, I., Souissi, A., Hosni, K., Brahim, N. B., Annabi, M., (2020) Essential oil and fatty acid composition of Melissa officinalis L., Progress in Nutrition, vol. 22 (n. 1), pp. 253-258.

[36] Bagdad, B.R., Cosge, B., (2006) The essential oil of lemon balm (Melissa officinalis L.), its components and using fields, J Fac Agri Onodokuz Mayis Univ., vol.21(1), pp.116121.

[37] Sari, A.O., Ceylan, A., (2002) Yield characteristics and essential oil composition of Lemon balm (Melissa officinalis L.) grown in the Aegean region of Turkey, Turk JAgric For., vol. 26, pp.217-224.

[38] Avci, A.B., Giachino, R.R.A., (2016) Harvest stage effects on some yield and quality characteristics of lemon balm (Melissa officinalis L.), Industrial Crops and Products, vol.88, pp. 23-27.

[39] Sadraei, H., Ghannadi, A., Malekshahi, K., (2003) Relaxant effect of essential oil of Melissa officinalis and citral on rat ileum contractions, Fitoterapia, vol. 74, pp.445-452.

[40] Bomme, U., Feicht, E., Rinder, R., (2002) Ergebnisse aus mehrja"hrigen Leistungspru"fungen mit ausgewa"hlten Herkünften von Zitronenmelisse (Melissa officinalis L.) (in German), Z Arznei- Gewurzpfla, vol.7, pp.422-432.

[41] Popova, A., Dalemska, Z., Mihaylova, D., Hristova, I., Alexieva, I., (2016) Melissa officinalis L.-GC profile and antioxidant activity, Int. J. Pharmacogn. Phytochem. Res. vol. 8, pp. 634-638.

[42] Pino, J.A., Rosado. A., Fuentes. V., (1999) Composition of the essential oil of Melissa officinalis L. from Cuba, J Essent Oil Res., vol. 11, pp.363-364.

[43] Carnat, A.P., Carnat, A., Fraisse, D., Lamaison, J., (1998) The aromatic and polyphenolic composition of lemon balm (Melissa officinalis. L. Su, bsp. officinalis) tea, Pharma Acta Helv., vol. 72, pp. 301-305.

[44] Shamsi, A.M., Amnzade, Y., Jahanshir, F., Jamshidi, A., (2005) Production of suspension cell culture in Melissa officinalis and comparison of produced secondary metabolites in callus versus whole plant, J. Med. plant, vol.13, pp. 68-71.

[45] Damien, D.H.J., Surai, P., Deans, S.G., (2000) In vitro antioxidant activity of plant essential oils and phytoconstituents, J Essent Oil Res., vol.12, pp.241-248.

[46] Hefendehl, F.W., (1970) Composition of etheric oil of Melissa officinalis L. and secondary changes of oil composition, Archiv Pharm., vol.303, pp.345-357

[47] Mrlianova, M., Tekelova, D., Felklova, M., Toth, J., Musil, P., Grancai, D., (2001) Comparison of the quality of Melissa officinalis L. cultivar Citra with Melissas of European origin, Pharmacospsychiatry Jul., vol.34 , Suppl 1, S20-21.

[48] Holla, M., Svajdlenka, E., Tekel, J., Vaverkova, S., Havranek, E., (1997) Composition of the essential oil from Melissa officinalis L. cultivated in Slovak Republic, J Essent Oil Res., vol.9, pp.481-484. 
[49] Dukic, N.M., Bozin, B., Sokovic, M., Simin, N., (2004) Antimicrobial and antioxidant activities of (Lamiaceae) essential oil, J Agric Food Chem., vol.52, pp. 2485-2489.

[50] Shalaby El-Gengaihi, A.S,, Khattab, M J., (1995) Oil of Melissa officinalis L. as affected by storage and herb drying, J Essent Oil Res., vol.7, pp.667-669.

[51] Barakat, S.A., Hudaib, M., El-Asad, N., Burns, D.T., (2016) Composition of volatile oil and methanolic extracts of Jordanian Melissa officinalis L. and actions against human cancer cell lines, Orient. J. Chem., vol.32, pp.2355-2362.

[52] Meftahizade, H., Sargsyan, E., Moradkhani, H., (2010) Investigation of antioxidant capacity of Melissa officinalis L. essential oils, J. Med. Plant Res., vol. 4(14), pp. 13911395.

[53] Van den Berg, T., Freundl, E., Czygan, F.C., (1997) Melissa officinalis subsp. altissima: characteristics of possible adulteration of lemon balm, Pharm., vol.52, pp. 803-808.

[54] Sharopov, F.S., Wink, M., Khalifaev, D. R., Zhang, H., Dosoky, N. S., Setzer, W.N., (2013) Composition and Bioactivity of the Essential Oil of Melissa officinalis L. Growing Wild in Tajikistan, International Journal of Traditional and Natural Medicines, vol. 2(2), pp. 86-96.

[55] Aziz, E. E., El-Ashry, S. M., (2009) Efficiency of show release urea fertilizer on herb yield and essential oil production of Lemon balm (Melissa officinalis L.) plants, Am.Eurasian J. Agric. Environ. Sci., vol.5, pp. 141-147.

[56] Norouzi, M., Soleimani, T., Pasha Zanousi, M., (2012) Essential oil component in leaf and flower of Lemon balm (Melissa officinalis L.)., Res. Pharmaceut. Sci., vol.7, p.749 